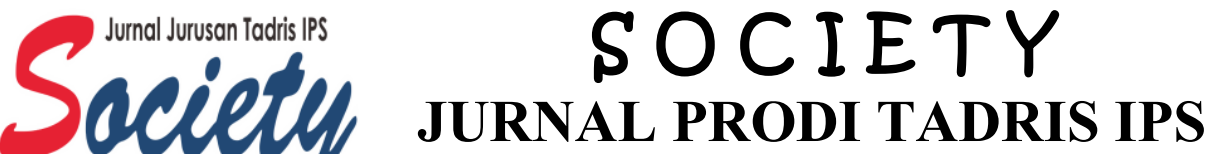

Volume 11, Nomor 1, Juni 2020

ISSN (p) : 2087-0493, ISSN (e) : 2715-5994

\section{MENINGKATKAN KEMAMPUAN GURU DALAM \\ MELAKSANAKAN MODEL PEMBELAJARAN KOOPERATIF BERBASIS \\ MASALAH MELALUI SUPERVISI KLINIS \\ DI SDN 07 MONTONG BETOK}

\author{
Amat \\ Guru SD Negeri 07 Montong Betok, Desa Montong Betok, Kab. Lombok Timur, \\ Nusa Tenggara Barat, Indonesia, Email. amatairaira@gmail.com
}

Diterima 15 April 2020 --- Disetujui 18 Mei 2020 --- Dipublikasikan 30 Juni 2020

\begin{abstract}
ABSTRAK
Tujuan penelitian ini adalah mengetahui meningkatan kemampuan guru dalam melaksanakan model kooperatif Pembelajaran Berbasis Masalah melalui supervisi klinis di SDN 07 Montong Betok Tahun pelajaran 2018/2019. Jenis penelitian ini adalah penelitian tindakan kelas (PTK). Subyek penelitian ini adalah 3 Orang Guru Kelas atas (4,5 dan 6) SDN 07 Montong Betok Kecamatan Montong Gading. Metode pengumpulan data dilakukan melalui metode wawancara, observasi, tes dan dokumentasi. Teknik analisis data menggunakan metode yang meliputi pengumpulan data, reduksi data, penyajian data, dan penarikan kesimpulan. Hasil penelitian ini perencanaan pembelajaran pada siklus 1 sebesar 54\% dengan kategori cukup, siklus 2 menjadi 80,33 \% dengan kategori baik sekali. Peningkatan kemampuan guru dalam proses pembelajaran model kooperatif berbasis masalah siklus 1 sebesar $60 \%$ dengan kategori cukup, siklus 2 menjadi 80,33 \% dengan kategori baik sekali. Peningkatan aktivitas guru dalam kegiatan bimbingan model pembelajaran kooperatif berbasis masalah pada siklus 1 sebesar $58,33 \%$ dengan kategori cukup, siklus 2 menjadi $90 \%$ dengan kategori baik sekali, Dengan demikian bahwa kemampuan guru dalam melaksanakan pembelajaran model kooperatif berbasis masalah pada kelas tinggi 4,5 dan 6 SDN 07 Montong Betok tahun pelajaran 2018/2019 melalui supervisi klinis dapat miningkatkan mutu pembelajaran.
\end{abstract}

Kata Kunci : Kemampuan Guru, Model Kooperatif, Supervise Klinis

\section{A. PENDAhuluan}

Dalam sistem pembinaan profesionalisme guru di SD/SMP bahkan di SMA diantara sekian banyak tugas Kepala Sekolah Dasar adalah melaksanakan supervisi klinis. Untuk melaksanakan supervisi klinis secara efektif diperlukan keterampilan konseptual, interpersonal dan teknikal. Oleh sebab itu, setiap kepala sekolah dasar harus memiliki dan menguasai konsep supervise klinis. Karena salah satudimensi kompetensi yang harus dikuasai kepala sekolah adalah dimensi supervise klinis. Dari delapan kompetensi pada dimensi akademik yang harus dimiliki kepala sekolah adalah kompetensi yang berkenaan dengan pemahaman utuh tentang proses belajar dan pembelajaran. Karena kepala sekolah dituntut untuk dapat memberikan pengarahan profesional pada masalah belajar dan 
pembelajaran yang terjadi di kelas. Hal ini sejalan dengan Acheron dan Gall (1987) yang mengatakan bahwa tujuan supervisi adalah untuk meningkatkan interaksi tatap muka dan membangun hubungan antara guru dan pengawas.

Pembinaan dengan memberi bantuan teknis kepada guru dalam melaksanakan proses. Pembelajaran merupakan kegiatan supervisi akademik yang bertujuan untuk meningkatkan kemampuan profesional guru dan meningkatkan kualitas pembelajaran. Menurut Blumberg (1980) dan Cogan (1973) peningkatan kualitas pembelajaran guru akan meningkatkan kualitas belajar peserta didik. Sehingga pembinaan dan pemberian dampingan secara kesinambungan yang dilakukan oleh kepala sekolah akan meningkatkan kualitas proses pembelajaran di kelas yang dilakukan oleh guru dan akan berdampak pada kualitas hasil belajar peserta didik.

Beberapa alasan yang mendasari pentingnya supervisi pengajaran. Pertama, supervise pengajaran bertujuan untuk meningkatkan kualitas pembelajaran di sekolah. Kedua, supervise pengajaran dapat memadukan perbaikan pengajaran secara relatif menjadi lebih sempurna secara bertahap. Ketiga, supervise pengajaran relevan dengan nuansa kurikulum yang berorientasi pada pencapaian hasil belajar secara tuntas, sehingga supervise pengajaran memberikan dukungan langsung pada guru di dalam mengupayakan tercapainya tingkat kompetensi tertentu pada siswa. Keempat, supervise pengajaran merupakan salah satu upaya untuk meningkatkan kualitas dan kemampuan para guru. Ketika seorang guru menjelaskan pelajaran di depan kelas, maka pada saat itu terjadi kegiatan mengajar, tetapi dalam kegiatan itu tak ada jaminan telah terjadi kegiatan belajar pada setiap siswa yang diajar. Kegiatan belajar mengajar (KBM) dikatakan efektif hanya apabila dapat mengakibatkan atau menghasilkan kegiatan belajar pada diri siswa. Peningkatan pengetahuan dan keterampilan guru diarahkan untuk peningkatan mutu pembelajaran dan diharapkan berdampak pada hasil belajar siswa. Tinggi rendahnya mutu pembelajaran dapat disebabkan oleh berbagai factor termasuk rendahnya wawasan profesionalisme guru.

Hasil pengamatan dalam supervisi di awal semester 2 Tahun Pelajaran 2018/2019 di SDN 07 Montong Betok menunjukkan bahwa guru cenderung kurang kreatif dan inovatif dalam proses pembelajaran, terbukti dari pengakuan guru-guru yang menjadi subjek dalam penelitian dengan menjadikan ceramah sebagai pilihan utama strategi mengajarnya. Strategi yang monoton kurang mampu memotivasi siswa dalam belajar serta kurang mampu menggali dan mengoptimalkan potensi siswa. Rahman (1999:4) mengemukakan bahwa rendahnya kualitas proses pembelajaran karena penggunaan metode mengajar yang monoton dan tidak bervariasi.

Di samping masalah di atas, supervise ini telah dapat menjaring beberapa jenis kesulitan yang dialami guru dalam pelaksanaan tugasnya di kelas, antara lain: 1) guru telah mampu menyusun RPP, namun belum cermat dalam menyesuaikan/ mencocokkan metode pembelajaran dengan kompetensi dasar (KD) mata pelajaran tersebut; 2) beberapa guru belum mahir/menguasai penggunaan media pembelajaran; 3) guru belum mampu menggunakan berbagai macam strategi pembelajaran yang kooperatif sehingga 
menimbulkan kebosanan pada siswa; 4) guru tidak mampu membuat/menciptakan media pembelajaran sendiri melainkan masih tergantung kepada media pembelajaran yang telah ada di sekolah, dan rata-rata guru belum mampu mengoperasikan perangkat TIK (teknologi informasi dan komunikasi) atau ICT (information and communication technology) dalam menunjang proses pembelajaran di kelas.

Subjek penelitian ini adalah 3 Orang Guru Kelas atas (4, 5 dan 6 ) SDN 07 Montong Betok Kecamatan Montong Gading tahun pelajaran 2018/2019. Sedangkan objek penelitian adalah bimbingan guru dalam supervisi akademik dalam rangka meningkatkan kemampuan dalam merencanakan dan melaksanakan pembelajaran model kooperatif.

Penelitian diadakan di SDN 07 Montong Betok Kecamatan Montong Gading tahun pelajaran 2018/2019 selama 3 (Tiga) bulan yaitu Februari s/d April 2019.

Penelitian ini dilakukan sebanyak 2 siklus. Tiap siklus terdiri dari 4 tahapan yaitu perencanaan, pelaksanaan, observasi dan evaluasi, refleksi.

Adapun langkah-langkah kegiatan setiap siklus dapat dijabarkan sebagai berikut. Perencanaan, Pelaksanaan (Tindakan), pengamatan dan evaluasi, dan Refleksi.

Teknik yang digunakan untuk mengumpulkan data yaitu observasi dan wawancara.

Observasi merupakan tahapan penelitian yang dilakukan pengawas sekolah/peneliti dengan kapasitas sebagai teman sejawat, dengan jalan mengadakan pengamatan terhadap obyek yang diteliti yaitu aktivitas guru pada saat kegiatan bimbingan dalam supervisi kepala sekolah berlangsung. Pengumpulan data melalui metode observasi ini menggunakan format pengamatan yang diisi oleh observer (pengawas sekolah) pada saat pemberian tindakan (bimbingan) dari kepala sekolah (peneliti). Adapun format observasi yang digunakan dalam penelitian ini terlampir.

Wawancara dilakukan oleh kepala sekolah dengan guru untuk mendapatkan informasi tentang bimbingan yang dilakukan oleh kepala sekolah (peneliti) baik dalam perencanaan maupun pelaksanaan proses pembelajaran.

Untuk mengetahui apakah melalui bimbingan ini efektif untuk meningkatkan kinerja kemampuan guru di dalam kelas pada SDN 07 Montong Betok tahun pelajaran 2018/2019 dari siklus I sampai siklus II sebagaimana yang diharapkan, dianalisis dengan menggunakan pendekatan kuantitatif yaitu dengan rumus statistik yang menunjukkan peningkatan aktivitas guru, peningkatan aktivitas kepala sekolah, serta peningkatan pemahaman guru tiap siklus. Sedangkan analisis kualitatif digunakan dengan deskripsi peningkatan hasil tindakan tiap siklus yang disusun secara rinci sesuai dengan kategorinya masing-masing.

Kemampuan guru dalam perencanaan pembelajaran

Peningkatan pemahaman setelah siklus I (X1)

$\mathrm{X} 1=$ Rata-rata hasil siklus $\mathrm{I}$ - rata-rata kondisi awal

$\mathrm{X} 1=\frac{\mathrm{X} 1}{\text { Rata-ratakondisi awal }} \times 100 \%$

Kemampuan guru dalam proses pembelajaran Peningkatan pemahaman setelah siklus I (X2) $\mathrm{X} 2$ = Rata-rata hasil siklus $\mathrm{I}$ - rata-rata kondisi awal

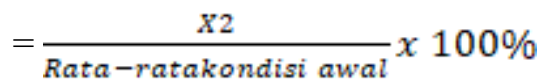


Peningkatan Aktivitas Guru (X3)

Peningkatan aktivitas setelah siklus I (X3)

X3 = Rata-rata hasil siklus I

Data yang diperoleh dari tindakan kemudian dianalisis untuk memastikan bahwa melalui supervisi, guru SDN 07 Montong Betok dapat meningkatkan kemampuan dalam pembelajaran menggunakan model kooperatif pembelajaran berbasis masalah (PBL)

Indikator keberhasilan dalam penelitian ini adalah jika terjadi peningkatan rata-rata kemampuanguru dalam perencanaan dan pelaksanaan pembelajaran tiap siklus. Untuk mengetahui kategori hasil kemampuan guru digunakan kategori sebagai berikut : $\mathrm{A}=$ baik sekali $\quad(76-100) \% \mathrm{~B}=$ baik $\quad(56-75) \quad \% \mathrm{C}=$ cukup $\quad(26-55) \% \mathrm{D}=\operatorname{kurang}(0-25) \%$

\section{B. HASIL PENELITIAN DAN PEMBAHASAN}

Penelitian ini dilaksanakan di SDN 07 Montong Betok . Populasi penelitiaannya adalah guru kelas 4,5 dan 6 TP 2018/2019. Penelitian ini dilaksanakan selama 3 bulan yaitu bulan Februari-April 2019.

Cara menentukan sampel dalam penelitian ini adalah melaksanakan supervisi. Bentuk supervisi yang digunakan pada setiap siklus adalah supervisi kelas dengan tujuan untuk mengukur kemampuan guru dalam menyusun perencanaan dan pelaksanaan pembelajaran kooperatif khususnya Pembelajaran Berbasis Masalah (Problem Based Learning). Hasil dari supervisi tersebut dianalisis untuk mencari masalah yang dihadapi guru kemudian dicarikan solusi cara mengatasinya dengan menelaah berbagai refrensi pelaksanaan pembelajaran.

Setelah peneliti mengadakan supervisi kelas pada guru kelas 4,5 dan 6 di SDN 07 Montong Betok TP. 2018/2019 diperoleh data awal berupa kondisi kompetensi kinerja guru. Hasil kompetensi dan kinerja guru dapat disajikan pada tabel 1 di bawah ini.

Tabel 1 Tabel Rekapitulasi Kemampuan Rata-rata Guru Hasil Observasi

\begin{tabular}{|c|c|c|c|c|c|c|}
\hline \multirow{2}{*}{ No. } & \multirow{2}{*}{ Nama Guru } & \multicolumn{2}{|c|}{ Nilai } & \multirow{2}{*}{ JML } & \multirow{2}{*}{ Rerata } & \multirow{2}{*}{ Kategori } \\
\cline { 3 - 4 } & & Perencanaan & Proses & & & \\
\hline 1 & Guru kelas 4 & 19 & 22 & 41 & 20,5 & kurang \\
\hline 2 & Guru kelas 5 & 19 & 21 & 40 & 20 & kurang \\
\hline 3 & Guru kelas 6 & 19 & 20 & 39 & 19,5 & kurang \\
\hline \multicolumn{2}{r|}{ Rata-rata } & 19 & 21 & 35,66 & 20 & kurang \\
\hline
\end{tabular}

Data di atas menunjukkan bahwa, 3 orang guru, diperoleh nilai rerata perencanaan pembelajaran dengan kategori kurang dan pelaksanaan pembelajaran juga dengan kategori kurang.

Berdasarkan data hasil supervisi di atas, maka peneliti menindaklajuti kondisi awal ini dengan merencanakan tindakan perbaikan dalam bentuk PTS dengan menerapkan bimbingan kelas. Penelitian ini dilakukan 2 siklus. Tiap siklus terdiri dari 4 tahapan yaitu perencanaan, pelaksanaan, observasi dan evaluasi serta refleksi.

\section{Hasil Penelitian}


Pada bagian hasil penelitian ini, peneliti akan memaparkan hasil penelitian tiap siklus.

\section{Siklus Pertama}

Siklus pertama dilaksanakan dari tanggal, 6 - 13 Februari 2019 Siklus pertama terdiri dari empat tahapan, yaitu perencanaan, pelaksanaan, obseravasi dan evaluasi, serta refleksi.

\section{a. Perencanaan}

Tahap perencanaan dilakukan pada tanggal 1-4Februuari 2019. Pada tahap ini peneliti mempersiapkan instrumen-instrumen yang dibutuhkan dalam tindakan perbaikan kemampuan guru yang dilaksanakan melalui penerapan bimbingan kelas. Adapun kegiatan yang dilakukan oleh peneliti pada tahapan perencanaan adalah membuat/menyusun program bimbingan, melayangkan jadwal kegiatan bimbingan bagi guru, membuat format daftar hadir, format observasi supervisi.

\section{b. Pelaksanaan Tindakan}

Tahapan pelaksanaan tindakan siklus 1 dilakukan pada 6-13 Februari 2019. Pada tahap ini peneliti melakukan bimbingan yang telah direncanakan melalui supervisi kelas.

\section{c. Observasi dan Evaluasi}

Selama kegiatan pembinaan berlangsung, observer (pengawas sekolah) mengamati kemampuan aktivitas guru dan kepala sekolah kemudian mengisi format observasi yang telah disiapkan (terlampir). Hasil observasi dapat dilihat pada tabel 2 di bawah ini.

Tabel 2 Rekapitulasi Hasil Observasi Kemampuan Guru dalam Perencanaan Pembelajaran Siklus 1

\begin{tabular}{|c|c|c|c|c|}
\hline No. & Nama Guru & Jumlah Nilai & Nilai Presentasi & Kategori \\
\hline 1 & Guru kelas 4 & 26 & 54 & Cukup \\
\hline 2 & Guru kelas 5 & 25 & 52 & Cukup \\
\hline 3 & Guru kelas 6A & 27 & 55 & Baik \\
\hline & Rata-rata & 26 & 54 & Cukup \\
\hline
\end{tabular}

Tabel 3 Rekapitulasi Hasil Observasi Kemampuan Guru dalam Proses Pembelajaran Siklus 1

\begin{tabular}{|c|c|c|c|c|}
\hline No. & Nama Guru & Jumlah Nilai & Nilai Presentasi & Kategori \\
\hline 1 & Guru kelas 4 & 32 & 56 & Baik \\
\hline 2 & Guru kelas 5 & 32 & 57 & Baik \\
\hline 3 & Guru kelas 6A & 35 & 60 & Baik \\
\hline & Rata-rata & 33 & 58 & Baik \\
\hline
\end{tabular}

Tabel 4 Hasil Observasi Aktivitas Guru Siklus 1

\begin{tabular}{|c|c|c|c|c|c|c|c|}
\hline \multirow{2}{*}{ No } & \multirow{2}{*}{ Nama Guru } & \multicolumn{3}{|c|}{ Nilai } & \multirow[t]{2}{*}{$\mathrm{Jml}$} & \multirow{2}{*}{$\begin{array}{l}\text { Kon } \\
\text { versi }\end{array}$} & \multirow{2}{*}{ Kategori } \\
\hline & & Interaksi & Aktivitas & Perhatian & & & \\
\hline 1 & Guru kelas 4 & 3 & 3 & 2 & 8 & 59 & cukup \\
\hline 2 & Guru kelas 5 & 2 & 3 & 2 & 7 & 50 & cukup \\
\hline 3 & Guru kelas 6A & 3 & 2 & 3 & 8 & 66 & cukup \\
\hline & Rata-rata & 2,6 & 2,6 & 2,3 & 7,66 & 58,33 & Cukup \\
\hline
\end{tabular}


Berdasarkan data di atas pada siklus pertama setelah dilakukan bimbingan, dari3 orang guru kemampuan dalam perencanaan pembelajaran memperoleh rerata 54 dengan kategori cukup. Rerata dalam pelaksanaan pembelajaran mencapai 58 kategori baik. Aktivitas guru 58,33 dengan kategori cukup. Sedangkan target keberhasilan $76 \%$. Artinya pelaksanaan tindakan berupa bimbingan kelas pada siklus pertama belum dinyatakan tuntas.

\section{d. Refleksi}

Pada tahapan ini, peneliti beserta teman sejawat mendiskusikan kembali hasil tindakan pada siklus I dengan melihat langkah-langkah yang sudah dicapai dan melihat kekurangankekurangan dari langkah-langkah/tindakan yang sudah dilakukan, yang nantinya akan diperbaiki pada siklus atau tindakan berikutnya.

\section{Siklus Kedua}

Siklus kedua dilaksanakan dari tanggal 15-25 Februari 2019. Siklus kedua terdiri dari empat tahapan, yaitu perencanaan, pelaksanaan, observasi dan evaluasi, serta refleksi. Berikut adalah hasil penelitian pada siklus kedua. a. Perencanaan

Kegiatan perencanaan siklus kedua dilakukan pada tanggal 14 Februari 2019. Pada tahap ini peneliti mempersiapkan instrumeninstrumen yang dibutuhkan dalam tindakan perbaikan kemampuan guru yang dilaksanakan melalui penerapan bimbingan kelas. Adapun kegiatan yang dilakukan oleh peneliti pada tahapan perencanaan adalah membuat/menyusun program bimbingan, melayangkan jadwal kegiatan bimbingan bagi guru, membuat format daftar hadir, format observasi supervisi.

b. PelaksanaanTindakan

Tahapan pelaksanaan tindakan siklus kedua dilakukan pada 20-24 Februari 2019. Pada tahap ini peneliti melakukan bimbingan yang telah direncanakan melalui supervisi kelas.

c. Observasi dan Evaluasi

Selama kegiatan pembinaan berlangsung, observer (pengawas sekolah) mengamati kemampuan aktivitas guru dan kepala sekolah kemudian mengisi format observasi yang telah disiapkan (terlampir). Hasil observasi dapat dilihat pada tabel berikut.

Tabel 5 Rekapitulasi Hasil Observasi Kemampuan Guru dalam Perencanaan Pembelajaran Siklus 2

\begin{tabular}{|c|c|c|c|c|}
\hline No. & Nama Guru & Jumlah Nilai & Nilai Presentasi & Kategori \\
\hline 1 & Guru kelas 4 & 35 & 79 & Baik \\
\hline 2 & Guru kelas 5 & 37 & 81 & baik Sekali \\
\hline 3 & Guru kelas 6A & 36 & 81 & Baik Sekali \\
\hline \multicolumn{2}{|r}{ Rata-rata } & 36 & 80,33 & Baik sekali \\
\hline
\end{tabular}

Tabel 6 Rekapitulasi Hasil Observasi Kemampuan Guru dalam Proses Pembelajaran Siklus 2

\begin{tabular}{|c|c|c|c|c|}
\hline No. & Nama Guru & Jumlah Nilai & Nilai Presentasi & Kategori \\
\hline 1 & Guru kelas 4 & 43 & 80 & Baik \\
\hline 2 & Guru kelas 5 & 44 & 81 & Baik sekali \\
\hline 3 & Guru kelas 6A & 44 & 80 & Baik \\
\hline \multicolumn{2}{r}{ Rata-rata } & 43,66 & 80,33 & Baik sekali \\
\hline
\end{tabular}


Tabel 7 Hasil Observasi Aktivitas Guru Siklus 2

\begin{tabular}{|c|c|c|c|c|c|c|c|}
\hline \multirow[b]{2}{*}{ No } & \multirow[b]{2}{*}{ Nama Guru } & \multicolumn{3}{|c|}{ Nilai } & \multirow[b]{2}{*}{ Jumlah } & \multirow{2}{*}{$\begin{array}{l}\text { Kon } \\
\text { versi }\end{array}$} & \multirow[b]{2}{*}{ Kategori } \\
\hline & & $\begin{array}{l}\text { Inte } \\
\text { raksi }\end{array}$ & $\begin{array}{l}\text { Akti } \\
\text { vitas }\end{array}$ & $\begin{array}{c}\text { Perha } \\
\text { Tian }\end{array}$ & & & \\
\hline 1 & Guru kelas 4 & 4 & 3 & 4 & 11 & 92 & baik sekali \\
\hline 2 & Guru kelas 5 & 3 & 4 & 4 & 11 & 92 & baik sekali \\
\hline 3 & Guru kelas 6 & 3 & 3 & 4 & 10 & 83 & baik sekali \\
\hline & Rata-rata & 3,3 & 3,3 & 4 & 10,66 & 90 & baik sekali \\
\hline
\end{tabular}

Berdasarkan data di atas pada siklus Siklus 1

kedua setelah dilakukan bimbingan, dari3 orang guru kemampuan dalam perencanaan pembelajaran memperoleh rerata $80,33 \%$ dengan kategori baik sekali. Rerata dalam pelaksanaan pembelajaran mencapai 80,33 \% kategori baiksekali. Aktivitas guru $90 \%$ dengan kategori baik sekali. Sedangkan target keberhasilan diatas $76 \%$. Artinya pelaksanaan tindakan berupa supervisi kelas pada siklus kedua dinyatakan tuntas.

\section{d. Refleksi}

Pada tahapan ini, peneliti beserta teman sejawat mendiskusikan kembali hasil tindakan pada siklus 2 dengan merefleksi langkah-langkah yang sudah dilakukan baik kelebihan dan kekurangan-kekurangan dari langkahlangkah/tindakan yang sudah dilakukan serta menganalisis data hasil pelaksanaan perencanaan, pelaksanaan pembelajaran dan observasi maka pada siklus II dinyatakan sudah berhasil.

\section{Pembahasan}

Berdasarkan perhitungan hasil observasi, selanjutnya akan dianalisis guna memperoleh kejelasan tentang pengaruh kegiatan supervisi yang bersifatklinis terhadap kemampuan guru dalam pembelajaran. Analisis ini akan diuraikan secara ringkas untuk tiap siklus seperti berikut.
Dari hasil pengamatan siklus satu, dapat dilihat peningkatan kemampuan guru dalam perencanaan dan proses pembelajaran serta aktivitas guru dalam kegiatan supervisi kelas dari kepala sekolah (peneliti), jika dibandingkan dengan data awal. Berdasarkan data hasil observasi, dapat dilihat bahwa rata-rata peningkatan kemampuan guru dalam perencanaan pembelajaran adalah sebesar $54 \%$ dengan kategori cukup, sedangkan kemampuan guru dalam proses pembelajaran sebesar 58\% dengan kategori cukup, serta peningkatan aktivitas guru dalam kegiatan bimbingan adalah sebesar 58,33\% dengan kategori cukup. Dari analisis ini dapat disimpulkan bahwa ada peningkatan kemampuan guru melalui kegiatan bimbingan dalam supervisi kelas siklus satu jika dibandingkan data sebelum dilakukan bimbingan.

\section{Siklus 2}

Dari hasil pengamatan siklus kedua, dapat dilihat peningkatan kemampuan guru dalam perencanaan dan proses pembelajaran serta aktivitas guru dalam kegiatan bimbingan dari kepala sekolah (peneliti), jika dibandingkan dengan hasil siklus pertama. Berdasarkan data hasil observasi, dapat dilihat bahwa rata-rata peningkatan kemampuan guru dalam perencanaan pembelajaran adalah sebesar 80,33\% dengan kategori baik sekali, sedangkan kemampuan guru 
dalam proses pembelajaran sebesar 80,33\% dengan kategori baik, serta peningkatan aktivitas guru dalam kegiatan bimbingan adalah sebesar 90 \% dengan kategori baik sekali. Dari analisis ini dapat disimpulkan bahwa ada peningkatan yang sangat signifikan terhadap kemampuan guru melalui kegiatan bimbingan dalam supervisi kelas siklus kedua sehingga penelitian dianggap sudah tuntas.

Dari hasil rekapitulasi dan grafik di atas dapat disimpulkan bahwa kemampuan guru dalam melaksankan model pembelajaran kooperatif berbasismasalahdi SDN 07 Montong Betok tahun pelajaran 2018/2019 dapat ditingkatkan melalui supervisi clinis.

\section{SIMPULAN DAN SARAN}

Peningkatan kemampuan guru dalam perencanaan pembelajaran model kooperatif berbasismasalahpada siklus 1 sebesar 54\% dengan kategori cukup, siklus 2 menjadi 80,33\% dengan kategori baik sekali.Peningkatan kemampuan guru dalam proses pembelajaran model kooperatif berbasismasalahsiklus 1 sebesar $60 \%$ dengan kategori cukup, siklus 2 menjadi 80,33 \% dengan kategori baik sekali. Peningkatan aktivitas guru dalam kegiatan bimbingan model pembelajaran kooperatif berbasis masalah pada siklus 1sebesar $58,33 \%$ dengan kategori cukup, siklus 2 menjadi 90 \% dengan kategori baik sekali,

Dengan demikian dapat disimpulkan bahwa kemampuan guru dalam melaksanakan pembelajaran model kooperatif berbasis masalah $\begin{array}{lllllll}\text { pada kelas tinggi } 4,5 & \text { dan } & 6 & \text { SDN } & 07\end{array}$
MontongBetok tahun pelajaran 2018/2019 melalui supervisi klinis dapat miningkatkan mutu pembelajaran.

\section{DAFTAR PUSTAKA}

Abror, Abd Rahman. 1999. Psikologi Pendidikan,Yogyakarta: PT. Tiara Wacana Yogya.

Acheson, K.A dan Gall, MD. 1987. Tecniques in the Clinical Supervisiona of Teacher. second edition. White Palin. NewYork: Longman.

Anita Lie. 2004. Cooperatif Learning. Jakarta. Grasindo.

Anwar. 2004. Pendidikan Kecakapan Hidup (Life Skill).

Arikuunto, S. 1993. Prosedur Penelitian Suatu Pendekatan Praktik, Rineka Cipta Jakarta.

Blumberg 1980 dan Cogan 1973. The Improvement off student learning through improvement of the teacher"s instruction.

Kamus Besar Bahasa Indonesia (KBI). 2008: 743.

Mohammad Surya. 2003. Psikologi Konseling. Pustaka Bani Quraisy: Bandung .

Nurhadi, dkk. 2003. Pembelajaran Kontektal dan Penerapannnya dalam KBK. Malang. Universitas Negeri Malang.

Pidarta, Made. 2000. Pemikiran tentang Supervisi Pendidikan: Sarana Press.

Sergiovani, Thomas J. 1987. The Principalship: arelective practice perspective.

Soedarso. 2001. Sistem Membaca Cepat dan Efektif. PT. Gramedia Pustaka Utama.

Sugiyono. 2010. Metode Penelitian Pendidikan. Bandung :Alfabeta.

Suryadi. 2018. Manajemen Mutu Berbasis Sekolah Konsep dan Aplikasi.

Team PPTK BPSDM Dikbud dan PMP Kemdikbud. 2014. Manajemen Kepemimpinan Sekolah (Bahan Ajar Implementasi K13). Jakarta Kementerian Pendidikan dan Kebudayaan.

Undang-Undang No. 14 tahun 2005 tentang Guru dan Dosen.

Usman Uzer. 1999. Menjadi Guru Profesional. Bandung: PT Remaja Rosdakarya. 